\title{
Enterococcus faecalis causes osteitis deformans in a Golden Lancehead snake (Bothrops insularis): a case report
}

\author{
Enterococcus faecalis causa osteíte deformante em uma serpente \\ Jararaca-ilhoa (Bothrops insularis): relato de caso
}

\author{
Viviane Campos Garcia ${ }^{1,2}$ (D); Pedro Enrique Navas-Suárez ${ }^{3}$; Ana Carolina Brandão de Campos Fonseca-Pinto ${ }^{4}$; \\ Silvana Maria Unruh4; Terezinha Knöbl3; Mirian Halásc Vac ${ }^{2,5}$; Claudia Momo; \\ Maria Alejandra Arias Lugo ${ }^{3}$; José Luiz Catão-Dias ${ }^{3}$; Selma Maria Almeida-Santos² \\ ${ }^{1}$ Universidade de São Paulo, Faculdade de Medicina Veterinária e Zootecnia, Departamento de Cirurgia - \\ Anatomia dos Animais Domésticos e Silvestres, São Paulo - SP, Brazil \\ ${ }^{2}$ Instituto Butantan, Laboratório de Ecologia e Evolução, São Paulo - SP, Brazil \\ ${ }^{3}$ Universidade de São Paulo, Faculdade de Medicina Veterinária e Zootecnia, Departamento de Patologia Experimental e Comparada, \\ São Paulo - SP, Brazil \\ ${ }^{4}$ Universidade de São Paulo, Faculdade de Medicina Veterinária e Zootecnia, Departamento de Clínica Cirúrgica Veterinária - \\ Diagnóstico por Imagem, São Paulo - SP, Brazil \\ ${ }^{5}$ Instituto Veterinário de Imagem, São Paulo - SP, Brazil
}

\begin{abstract}
Osteitis deformans (Paget's disease) is a chronic bone disorder characterized by excessive osteoclast-mediated bone resorption followed by new bone formation. The present paper reports this condition in an 18-year-old captive golden lancehead (Bothrops insularis) from Brazil. This patient initially exhibited anorexia and swelling in the middle third of the spine associated with locomotor disability. For diagnosis, radiography, ultrasound, computed tomography, cytology, and microbiological culture were performed. Diagnostic imaging showed bone changes, vertebral fusion, and bone proliferation. Cytology revealed blood cells how toxic heterophiles, reactive monocytes, young red blood cells, and polychromasia compatible with an infectious process. A bacterial culture identified an ampicillin-susceptible strain of Enterococcus faecalis. Antibiotic treatment was promptly started, but the snake died 25 days later. Histopathologically, the bone tissue showed a generalized thickening of the vertebral trabeculae. For the first time, the presence of E. faecalis associated with the development of osteitis deformans in snakes was presented.
\end{abstract}

Keywords: Reptiles. Bone pathology. Paralysis. Captive breeding. Proliferative bone diseases.

\section{RESUMO}

Osteíte deformante (Doença de Paget) é um distúrbio ósseo crônico caracterizado por reabsorção óssea excessiva mediada por osteoclastos, seguida por nova formação óssea. O presente trabalho relata essa condição em uma serpente jararaca-ilhoa (Bothrops insularis) do Brasil de 18 anos. O paciente apresentou inicialmente anorexia e um inchaço no primeiro terço médio da coluna associado com a incapacidade locomotora. O diagnóstico foi estabelecido com o apoio de radiografia, ultrassonografia, tomografia computadorizada, citologia e cultura microbiológica. O diagnóstico por imagem mostrou alterações ósseas, fusão de vértebras e proliferação óssea. A citologia mostrou células sanguíneas como heterófílos tóxicos, monócitos reativos, células sanguíneas jovens e policromasia compatíveis com um processo infeccioso. A cultura bacteriana identificou uma cepa de Enterococcus faecalis suscetível à ampicilina. $\mathrm{O}$ tratamento com antibióticos foi iniciado imediatamente, mas a serpente morreu 25 dias depois. Histopatologicamente, o tecido ósseo mostrou um espessamento generalizado das trabéculas vertebrais. Portanto, foi demonstrado pela primeira vez a presença de E. faecalis associada ao desenvolvimento de osteíte deformante em uma serpente.

Palavras-chave: Répteis. Patologia óssea. Paralisia. Criação em cativeiro. Doenças ósseas proliferativas. 


\section{Correspondence to:}

Viviane Campos Garcia

Universidade de São Paulo, Faculdade de Medicina Veterinária

e Zootecnia, Departamento de Cirurgia - Anatomia dos

Animais Domésticos e Silvestres

Av. Prof. Dr. Orlando Marques de Paiva, 87

CEP: 05508-270, São Paulo - SP, Brazil

e-mail:vivigarcia@usp.br

Received: November 07, 2019

Approved: October 14, 2020

How to cite: Garcia VC, Navas-Suárez PE, Fonseca-Pinto ACBC, Unruh SM, Knöbl T, Vac MH, Momo C, Arias Lugo MA, Catão-Dias JL, Almeida-Santos SM. Enterococcus faecalis causes osteitis deformans in a Golden Lancehead snake (Bothrops insularis): a case report. Braz J Vet Res Anim Sci. 2020;57(4):e163926. https://doi.org/10.11606/ issn.1678-4456.bjvras.2020.163926

Chronic bone disorders cause new bone remodeling, which in turn leads to increased osteoclast-mediated resorption and bone neoformation. This new bone remodeling results in bone disorganization and a lamellar mosaic triggering a painful disease known as osteitis deformans (Paget's disease) (Isaza et al., 2000). Reptile husbandry has improved considerably in recent years, thus increasing the life expectancy of captive individuals and the risk of developing degenerative diseases (Mader, 2006; Frye, 2007). Accordingly, proliferative spinal osteoarthropathy has been increasingly reported in captive reptiles (Isaza et al., 2000; Preziosi et al., 2007). While the cause is unknown, a viral agent or autoimmune etiology may be involved (Kiel, 1983; Mader, 2006). Clinical signs can include vertebral column stiffness with pain and result in decreased mobility, including ankylosis, osteolysis, osteoporosis, and occasionally pathologic fractures. Motor deficits in somatic musculature, slight or dramatic torsion of the body below the affected area, torticollis, trembling, and subtle or acute spinal kinking may be exhibited. Affected snakes may not be able to balance on a hook, right themselves if placed in dorsal recumbency, or effectively strike at prey objects (Fitzgerald \& Vera, 2006). Radiography was used to assist in diagnosis. However, the complete diagnosis depends on clinical history, physical examination, blood culture, bone culture, histopathology, and necropsy findings (Fitzgerald \& Vera, 2006). The differential diagnosis may be gout, fibrous osteodystrophy, trauma, bone tumor, and tumoral calcinosis (Mader, 2006; Stahl, 2013). The treatment is difficult and it is necessary to identify a causative agent. Effective treatment includes appropriate antimicrobial selection, surgical debridement of granulomatous or lytic areas, use of anti-inflammatory medications, and separation of affected and unaffected individuals. Therapy should be applied for the long-term (Antinoff, 1997; Fitzgerald \& Vera, 2006). At present, the prognosis for snakes with this condition is poor to grave and most of them are euthanized (Frye \& Carney, 1974; Fitzgerald \& Vera, 2006; Preziosi et al., 2007). The present paper reports a case of osteitis deformans in a captive golden lancehead (Bothrops insularis) using diagnostic imaging (radiography, ultrasonography, and computed tomography) and microbiological and histopathological examinations.

An 18-year-old female golden lancehead from the collection of the Butantan Institute (São Paulo, Brazil) showed clinical signs of anorexia and locomotor disability. Physical examination revealed swelling in the middle third of the vertebral column. The swelling was characterized by a solid, irregular, and firm surface, but with a normal muscle mass. To diagnose this condition, the animal was moved to the Veterinary Hospital of the School of Veterinary Medicine and Animal Science at the University of São Paulo to perform radiography, ultrasonography, and computed tomography-guided fine-needle aspiration cytology (for evaluation and culture of bacteria and fungi).

Lateral and dorsoventral radiographs were taken using a scalable digital radiography system (DR 400, Agfa). Ultrasonographic scans were performed using a SonoSite ultrasound with a 5-10 MHz linear array probe (SonoSite Titan, Bothell, WA, USA). Computed tomography was performed using a 16-channel multirow-detector scanner (Philips MX 8000 IDT, Philips Medical Systems, Best, The Netherlands). The aspirates obtained for cytology were stained using the quick panoptic method (Quick Panoptic test, Newprov ${ }^{\circledR}$, Pinhais, Brazil) and subjected to bacterial and fungal culture. The aspirates obtained were incubated for fungal research in Sabouraud Dextrose agar (Laborclin, Paraná, Brazil), incubated at $25^{\circ} \mathrm{C}$ for four weeks. For bacterial culture, the aspirates were incubated in BHI broth (at $37^{\circ} \mathrm{C}$ for $18 \mathrm{~h}$ ) and seeded on Columbia agar with $5 \%$ sheep blood $\left(\right.$ Oxoid $^{\text {tw }}$ Agar Technical, Ontario, Canada), tryptic soy agar, and MacConkey agar (Difco Laboratories, Detroit, MI, USA). The agar plates were then incubated at $37^{\circ} \mathrm{C}$ for $24 \mathrm{~h}$. The biochemical identification of strains was performed by turbidity analysis using the automated Vitek system (BioMérieux, Marcy-l'Étoile, France). The phenotypic resistance profile of the isolates was determined using the disc diffusion technique for ampicillin $(10 \mu \mathrm{g})$, high-concentration gentamicin $(120 \mu \mathrm{g})$, and vancomycin $(30 \mu \mathrm{g})$. For that, we followed the recommendations of the Clinical and Laboratory Standards Institute (Sweeney et al., 2008). 
Radiographs indicated osteosclerosis, ankylosis of the costovertebral joints, segmental fusion, and proliferation of multiple vertebrae and ribs of a segment adjacent to the affected vertebra. In the vertebrae, the proliferative bone was fused to the joint spaces of the lateral facet and the ventrocaudal margins of the vertebral condyles (Figure 1A, B). Ultrasonography revealed an irregular vertebral surface with an acoustic shade and bone demineralization (Figure 1C). The liver was enlarged, homogeneous, and hypoechoic except for some disperse hyperechoic foci. The spleen was homogeneous and hypoechoic, and the pancreas was enlarged. Computed tomography (Figure 1D-G) confirmed the radiographic findings. The cytology of the lesions of the affected bone region revealed toxic heterophils, reactive monocytes, polychromasia, and young red blood cells consistent with an infectious process. Bacterial cultures showed that spinal osteoarthritis was infected with an ampicillin-susceptible strain of Enterococcus faecalis. Fungal culture was negative, five days after the incubation, and remaining negative for four weeks. After diagnosis, the snake was given an intramuscular injection of $10 \mathrm{mg} / \mathrm{kg}$ ampicillin (ampicillin for injectable suspension, $2 \mathrm{~g} / \mathrm{ml}$;
Vetnil, Brazil) daily for five days. After treatment with an antibiotic, the snake showed some clinical improvement.

The snake died 25 days after antibiotic therapy. The snake was necropsied, and organ and tissue fragments were collected and fixed in $10 \%$ buffered formalin. The affected vertebral fragment was decalcified in EDTA solution, dehydrated embedded in paraffin, sectioned at $5 \mu \mathrm{m}$, and stained with hematoxylin and eosin for histopathological examination. Necropsy revealed an enlarged liver, with two nodules of approximately $2 \mathrm{~cm}$ each (black arrow) (Figure $2 \mathrm{~A}$ ) and hemorrhagic kidney (Figure 2B). The lungs and air sacs were hyperemic and with excessive mucus production. The vertebral column showed sites of irregular bone proliferation with vertebral fusion and loss of joint function. The microscopic characteristics of the affected vertebral segment were suggestive of spondyloarthritis with intralesional Gram-positive bacterial colonies (Figure 3A). The cortical bone and transverse and spinous processes of the affected vertebra were eccentrically expanded by the newly formed bone tissue, which elevated the periosteum and caused atrophy of the overlying musculature (Figure 3B). The intervertebral discs showed evidence of degeneration, mineralization, and chondroma formation.
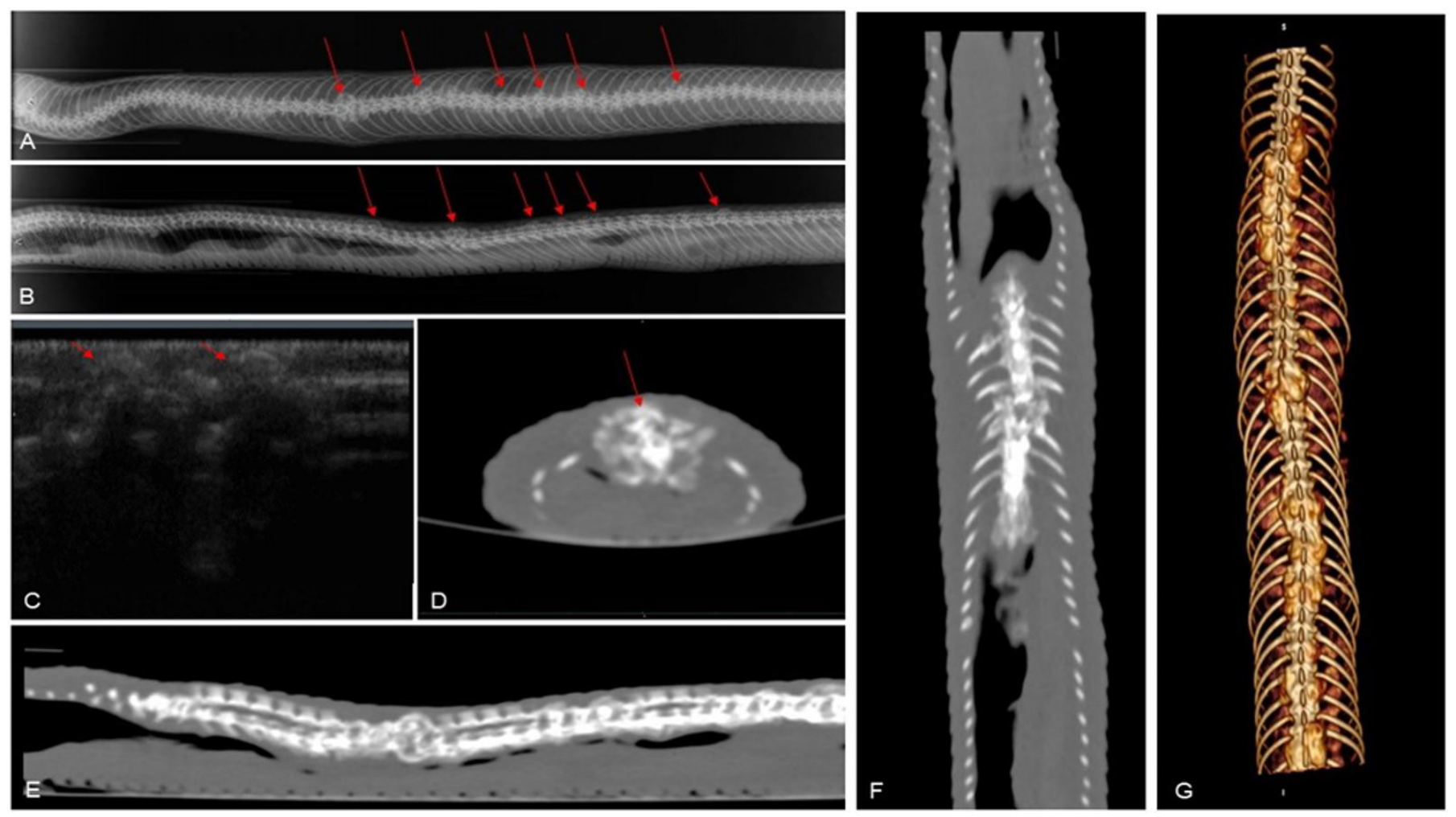

Figure 1-Radiographic, ultrasound, and computed tomography images of a captive golden lancehead (Bothrops insularis). (A) Dorsoventral and (B) right lateral recumbent radiographs of the middle third of the body showing areas of sclerosis and ankylosis in the costovertebral joints, segmental fusion, and proliferation of multiple vertebrae and ribs (arrows); (C) Ultrasound image of the vertebral column showing an irregular bone surface with an acoustic shade and bone demineralization; (D-G) Computed tomography images showing an extensive amorphous bone proliferation involving the bone margins, vertebral processes, and some ribs of the middle segment of the spine; (D) Cross-sectional view; note sclerosis (arrow) associated with the osteolytic areas in the vertebral body affecting the vertebral canal; (E) Sagittal view; (F) dorsal view; and $(\mathrm{G})$ three-dimensional (3D) volume rendering of the dorsal view. 

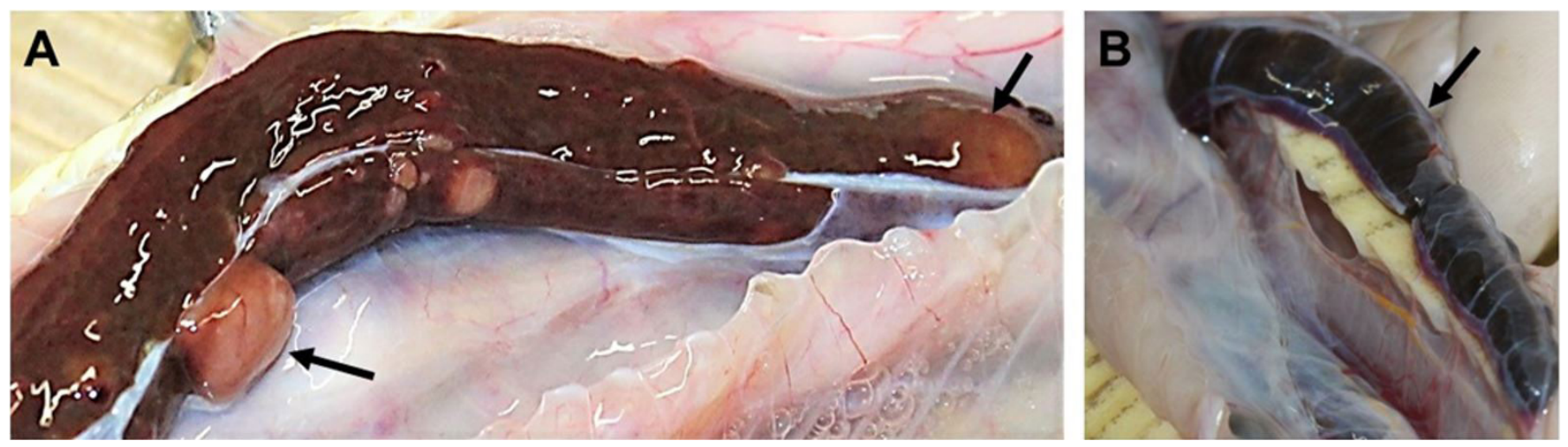

Figure 2- Macroscopic evaluated. (A) Enlarged liver with two nodules of $2 \mathrm{~cm}$ (black arrow) and several dispersed smaller nodules; (B) Hemorrhagic kidney (black arrow).

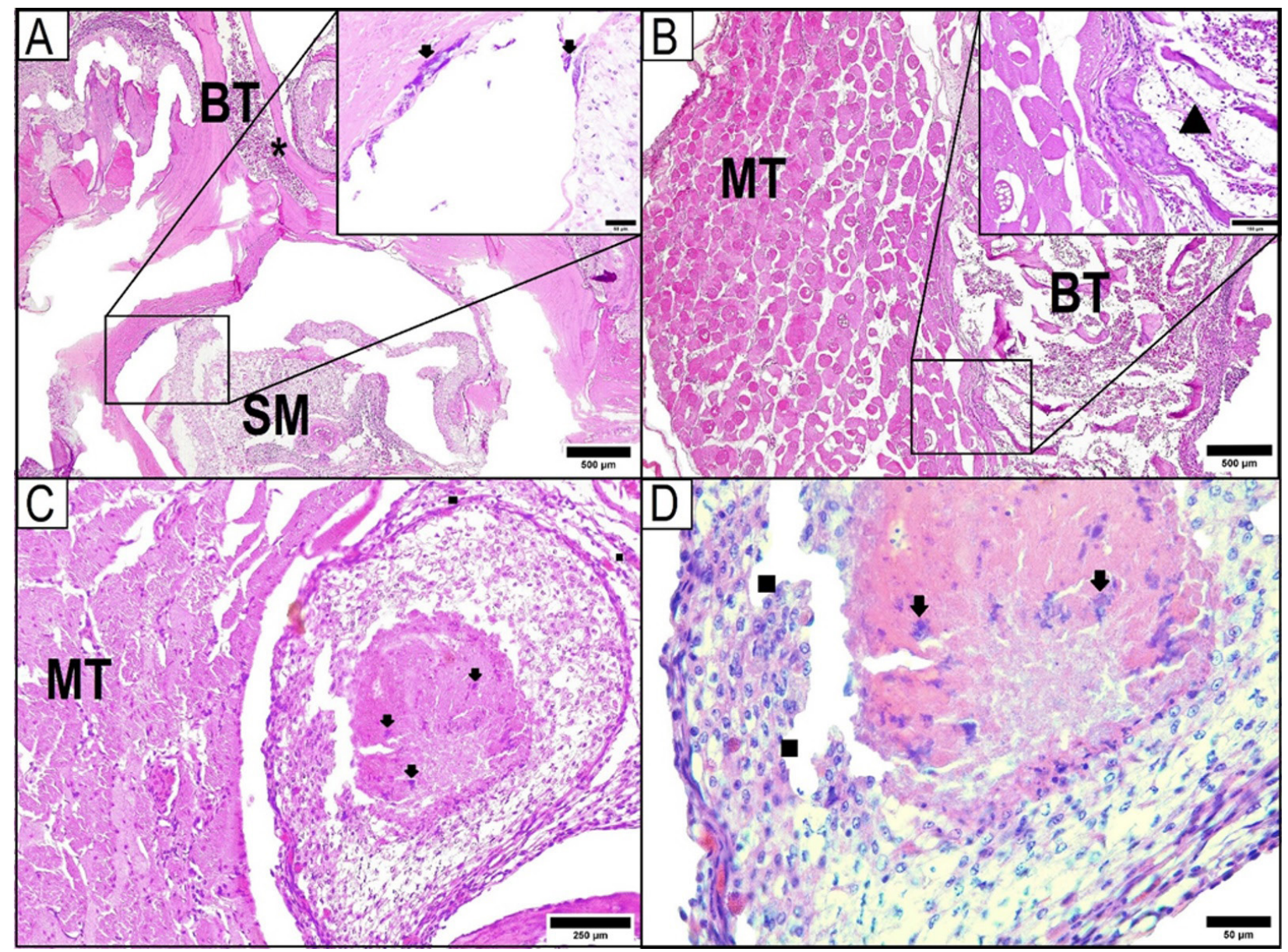

Figure 3 - Transverse sections of the vertebral bone tissue of a captive golden lancehead (Bothrops insularis) with osteitis deformans. $\mathrm{SM}=$ Spinal medullae, MT= Muscular tissue, BT= Bone tissue. (A) The cortical bone of the transverse processes is eccentrically expanded by the newly formed bone tissue, thus elevating the periosteum (asterisk), Scale bar= 500 microns. The inset highlights the presence of multiple bacterial colonies within the vertebral canal (black arrow), Scale bar $=50$ microns; (B) The cortical bone of the transverse processes is eccentrically expanded by the newly formed bone tissue (inset, black triangle), Scale bar=500 microns, thus elevating the periosteum and leading to atrophy of the overlying musculature, Scale bar=150 microns; (C) Vertebra showing inflammatory cell infiltrates (black square) and multiple bacterial colonies (black arrow), Scale bar= 250 microns; (D) Vertebra showing the pleocellular inflammatory response (black square) to multiple bacterial colonies (black arrow), Scale bar $=50$ microns. Hematoxylin-eosin.

Moreover, the intervertebral discs exhibited pleocellular inflammatory infiltrates with fibroplasia, which extended to the adjacent marrow spaces and obliterated the vertebral canal (Figure 3C, D). Other microscopic findings were moderate multifocal pyogranulomatous hepatitis, moderate multifocal cholestasis, moderate multifocal mixed (macro and microgoticular) steatosis; moderate multifocal hemosiderosis in the liver, spleen, and kidney; mild to moderate multifocal myofiber atrophy and necrosis and mild focal heterophilic pericarditis. We found no noteworthy alterations in the other 
tissues. The causative agents of infectious processes were not investigated due to difficulty collecting the material. In the liver, histopathological evaluations found inflammatory changes and no bacterial colony. The infectious process may have started in the liver and spread to the spine. There was no sepsis. Bacterial colonies were found only in the spine that showed spinal injury, which was the cause of death.

Osteitis deformans is a chronic degenerative osteoarticular disease resulting from repeated cycles of bone resorption and deposition (Frye \& Carney, 1974). This disease causes an increase in bone volume, which compresses blood vessels and nervous structures. The bones become dense and brittle, resulting in deformities and pain (Isaza et al., 2000; Mader, 2006; Preziosi et al., 2007; Ocarino et al., 2008; Stahl, 2013). This degenerative process increases osteoclast-mediated bone resorption and disorganizes osteoblastic bone repair (Frye \& Carney, 1974). Osteitis deformans usually affect geriatric patients. A complete diagnosis is made through clinical history, laboratory exams, blood culture, bone culture, necropsy, and histopathology. The etiology still needs further investigations, but various factors seem to be implicated in the pathogenesis of the disease (Frye \& Carney, 1974). Increased bone resorption and formation are the main features that differentiate osteitis deformans from other bone diseases (Frye \& Carney, 1974). Nevertheless, diseases such as gout, fibrous osteodystrophy, trauma, bone tumor, and tumoral calcinosis should be considered in the differential diagnosis (Mader, 2006; Stahl, 2013).

Individuals with osteitis deformans develop bone compensation that causes bone hardening and vertebral fusion (Preziosi et al., 2007). Radiography showed bone alterations and confirmed the diagnosis of spinal disease (Dickie, 2010). Ultrasonography complemented the radiographic examination by evaluating the contours of the bone surface and determining bone irregularities. Computed tomography determined the sites of active disease. In humans, genetic factors are a potential cause of osteitis deformans, but viral pathogens may also be etiological agents (Reddy et al., 2001; Roodman \& Windle, 2005; Ocarino et al., 2008). In snakes, osteitis deformans was first described in 1974, and viral pathogens (e.g., mouse polyomavirus) have been suggested as etiological agents (Frye \& Carney, 1974; Galiová et al., 2010). However, chronic infections with Pseudomonas spp., Klebsiella spp., Morganella morganii, Salmonella arizonae, Staphylococcus spp., and Providencia rettgeri are also suggested as playing a role in the pathogenesis, triggering autoimmune diseases (Preziosi et al., 2007). In this case report, a pure culture of Enterococcus faecalis was isolated from a snake with bone disease. Enterococci include Gram-positive bacteria present in the human and animal microbiome (Shek et al., 2009; Fiore et al., 2019; Cabral et al., 2020). There are over 50 species of Enterococcus and most of them are commensal, but some opportunistic lineages of E. faecalis and E. faecium are often associated with extraintestinal infections, including urinary tract infections, endocarditis, and sepsis (Fiore et al., 2019). Limited susceptibility to antibiotics due to intrinsic and acquired mobile resistance represents an additional concern in nosocomial infections by enterococci (Hollenbeck \& Rice, 2012).

Enterococcus faecalis can also cause osteoarticular diseases in humans and animals (mainly in chickens), although these infections are reported less frequently (Vlahakis et al., 2003; Braga et al., 2018). Enterococcus sp. has been reported in advanced osteomyelitis of the spine in a euthanized snake, Bitis nasicornis. Microscopic examination of the spine revealed multifocal necrosis and proliferating bone tissue associated with massive infiltration of bone marrow and bone tissue with heterophils. Necropsy revealed a degenerative process of the liver compatible with chronic inflammatory disease of the spine (Schröter et al., 2005). Osteoarticular infections in snakes have been poorly studied, but the presence of enterococci in the oral microbiota of snakes is well documented (Shek et al., 2009; Barbosa et al., 2018; Résière et al., 2018). In reptilian samples, Enterococcus spp. were the most frequently isolated gram-positive bacteria susceptible to ampicillin (83\%) (Tang et al., 2020).

The environmental persistence of agents and dysbiosis may function as predisposing factors for bacterial translocation from the intestine to extraintestinal sites. The tissue damage caused by E. faecalis in extraintestinal infections is the result of the host's inflammatory cascade and the direct action of the release of cytolysin, serine, and metalloproteases (Fiore et al., 2019). In such cases, animal diseases should be treated with ampicillin or aminoglycoside-based antibiotics, although the prognosis is poor (Frye, 2007).

In the present investigation, the snake had a short period (five days) of antibiotic therapy. According to Isaza et al. (2000), transient bacteremia causes pathogenesis of proliferative bacterial osteoarthritis and, if identified early, aggressive antibiotic therapy is beneficial.

Therefore, in the histopathological examination, we found only the presence of bacterial colonies in the vertebral segment, which does not indicate sepsis as the cause of death. A case of sepsis in a turtle revealed numerous bacterial emboli in multiple tissues (Murray et al., 2009). In the chameleon, the histopathological evaluation revealed acute septicemia characterized by numerous intravascular acid-fast bacteria and intravascular fibrin thrombi in 
multiple organs (Martinson et al., 2019). Septicemia in reptiles is often associated with the presence of petechiae and ecchymosis, which are believed to be secondary to vascular damage caused by endotoxin release (Frye, 2007).

In conclusion, this is the first report of osteitis deformans in snake caused by E. faecalis, including descriptions of radiographic, ultrasonographic, tomographic, and pathological findings.

\section{Conflict of Interest}

None of the authors of this article have a financial or personal relationship with other people or organizations that could inappropriately influence or bias the content of the article.

\section{References}

Antinoff N. Osteomyelitis in reptiles. Proc Assoc Rept Amph Vet. 1997;4:149-52.

Barbosa LN, Ferreira RS Jr, Mello PL, Garces HG, Chechi JL, Frachin T, Barros LC, Bosco SMG, Bagagli E, Fernandes A Jr, Barraviera B, Santos LD. Molecular identification and phylogenetic analysis of Bothrops insularis bacterial and fungal microbiota. J Toxicol Environ Health A. 2018;81(6):142-53. http://dx.doi.org/10.1080/15287394.2 017.1395581 PMid:29319420.

Braga JFV, Leal CAG, Silva CC, Fernandes AA, Martins NRDS, Ecco R. Genetic diversity and antimicrobial resistance profile of Enterococcus faecalis isolated from broilers with vertebral osteomyelitis in Southeast Brazil. Avian Pathol. 2018;47(1):14-22. http://dx.doi.org/10.1080/03079457.20 17.1359403 PMid:28737063.

Cabral BG, Davies Y, Menão MC, Saidenberg A, Gomes VTM, Moreno LZ, Sato MIZ, Moreno AM, Knöbl T. Companion psittacine birds as reservoir of gentamicin and vancomycin-resistant Enterococcus spp. Pesq Vet Bras. 2020;40(2):129-33. http://dx.doi.org/10.1590/1678-5150pvb-6147

Dickie A. Ultrassonografia do sistema musculoesquelético. In: Mannion P, editor. Ultrassonografia de pequenos animais. 1. ed. Rio de Janeiro: Revinter; 2010. p. 251-5.

\section{Ethics Statement}

This study was conducted under the approval of the Animal Ethics Committee of the School of Veterinary Medicine and Animal Science of the University of São Paulo (approval number 2732151216/2017).

\section{Acknowledgements}

This study was financed in part by Coordenação de Aperfeiçoamento de Pessoal de Nível Superior - Brasil (CAPES) - Finance Code 001 and the Conselho Nacional de Desenvolvimento Científico e Tecnológico (CNPq) (\#310357/2018-7). We thank Adriano Fellone, Kelly Kishi, Marcio Candido (for the assistance of radiographic images), and Henrique Braz for reviewing the language of the manuscript.

Fiore E, Van Tyne D, Gilmore MS. Pathogenicity of Enterococci. Microbiol Spectr. 2019;7(4): http://dx.doi. org/10.1128/microbiolspec.GPP3-0053-2018 PMid:31298205.

Fitzgerald KT, Vera R. Spinal osteopathy. In: Mader DR, editor. Reptile medicine and surgery. 2nd ed. Philadelphia: Elsevier Saunders; 2006. p. 906-12. http://dx.doi.org/10.1016/ B0-72-169327-X/50073-0.

Frye FL, Carney J. Osteitis deformans (Paget's disease) in a boa constrictor. Vet Med Small Anim Clin. 1974;69(2):1868. PMid:4492815.

Frye FL. Doenças infecciosas: doenças fúngicas, por actinomicetos, bacterianas, rickettsiais e virais. In: Vilani RG, editors. Grupo Fowler: avanços na medicina de animais selvagens medicina de répteis. 1a ed. Curitiba: Fotolaser Gráfica e Editora; 2007. p. 89-155.

Galiová M, Kaiser J, Novotný K, Ivanov M, Fišáková MN, Mancini L, Tromba G, Vaculovic T, Liska M, Kanický V. Investigation of the osteitis deformans phases in snake by double-pulse laser-induced breakdown spectroscopy. Anal Bioanal Chem. 2010;398(2):1095-107. http://dx.doi. org/10.1007/s00216-010-3976-1 PMid:20628874.

Hollenbeck BL, Rice LB. Intrinsic and acquired resistance mechanisms in enterococcus. Virulence. 2012;3(5):42133. http://dx.doi.org/10.4161/viru.21282 PMid:23076243. 
Isaza R, Garner M, Jacobson E. Proliferative osteoarthritis and osteoarthrosis in 15 snakes. J Zoo Wildl Med. 2000;31(1):207. http://dx.doi.org/10.1638/1042-7260(2000)031[0020:PO AOIS]2.0.CO;2 PMid:10884119.

Kiel JL. Paget's disease in snakes. In: Proceedings of the Annual Meeting of the American Association of Zoo Veterinarians; 1983; Tampa, FL. Tampa: American Association of Zoo Veterinarians; 1983. p. 201-7.

Mader DR. Metabolic bone diseases. In: Mader DR, editor. Reptile medicine and surgery. 2nd ed. Philadelphia: Elsevier Saunders; 2006. p. 850. http://dx.doi.org/10.1016/B0-72169327-X/50065-1.

Martinson SA, Skjonsberg C, Muckle CA, Spears J. Acute septicemia in a hermaphrodite veiled chameleon (Chamaeleo calyptratus) infected with Mycobacterium chelonae Chemovar niacinogenes. J Herpetological Med Surg. 2019;29(1-2):21-6. http://dx.doi.org/10.5818/18-04-150.1

Murray M, Waliszewski NT, Garner MM, Tseng FS. Sepsis and disseminated intravascular coagulation in an eastern spiny softshell turtle (Apalone spinifera spinifera) with acute mycobacteriosis. J Zoo Wildl Med. 2009;40(3):572-5. http:// dx.doi.org/10.1638/2008-0125.1 PMid:19746876.

Ocarino NM, Goulart CE, Falci SM, Souza PC, Serakides R. Osteopetrosis and osteonecrosis in snake Boa constrictor. Arq Bras Med Vet Zootec. 2008;60(5):1284-7. http://dx.doi. org/10.1590/S0102-09352008000500039

Preziosi R, Diana A, Florio D, Gustinelli A, Nardini G. Osteitis deformans (Paget's disease) in a Burmese python (Python molurus bivittatus): a case report. Vet J. 2007;174(3):669-72. http://dx.doi.org/10.1016/j.tvjl.2006.11.012 PMid:17222574.

Reddy SV, Kurihara N, Menaa C, Roodman GD. Paget's disease of bone: a disease of the osteoclast. Rev Endocr Metab Disord. 2001;2(2):195-201. http://dx.doi. org/10.1023/A:1010010912302 PMid:11705325.

Résière D, Olive C, Kallel H, Cabié A, Névière R, Mégarbane B, Gutiérrez JM, Mehdaoui H. Oral microbiota of the snake Bothrops lanceolatus in Martinique. Int J Environ Res Public Health. 2018;15(10):2122. http://dx.doi.org/10.3390/ ijerph15102122 PMid:30261677.
Roodman GD, Windle JJ. Paget disease of bone. J Clin Invest. 2005;115(2):200-8. http://dx.doi.org/10.1172/ JCI24281 PMid:15690073.

Schröter M, Heckers KO, Rüschoff B, Laufs R, Mack D. Severe case of spinal osteomyelitis due to Enterococcus spp. in a three-year old Rhinoceros Horned Viper, Bitis nasicornis. J Herpetological Med Surg. 2005;15(3):53-6. http://dx.doi.org/10.5818/1529-9651.15.3.53

Shek KC, Tsui KL, Lam KK, Crow P, Ng KH, Ades G, Yip KT, Grioni A, Tan KS, Lung DC, Lam TS, Fung HT, Que TL, Kam CW. Oral bacterial flora of the Chinese cobra (Naja atra) and bamboo pit viper (Trimeresurus albolabris) in Hong Kong SAR, China. Hong Kong Med J. 2009;15(3):183-90. PMid:19494373.

Stahl S. Reptile: proliferative spinal osteoarthropathy. In: Mayer J, Donnelly T, editors. Clinical veterinary advisor: birds and exotic pets. 1st ed. Philadelphia: Saunders Company; 2013. p. 135-6.

Sweeney MT, Diaz-Campos DV, Bowden R, Fritsche TR, Hayes J, Langston C, Lubbers BV, Martin-Jimenez T, Miller C, Pallotta C, Papich MG, Parkinson A, Schwarz S, Traczewski MM. Performance standards for antimicrobial disk and dilution susceptibility tests for bacteria isolated from animals, VET01. 5th ed. Wayne, PA: Clinical and Laboratory Standards Institute; 2018.

Tang PK, Divers SJ, Sanchez S. Antimicrobial susceptibility patterns for aerobic bacteria isolated from reptilian samples submitted to a veterinary diagnostic laboratory: 129 cases (2005-2016). J Am Vet Med Assoc. 2020;257(3):305-12. http://dx.doi.org/10.2460/javma.257.3.305 PMid:32657653.

Vlahakis NE, Temesgen Z, Berbari EF, Steckelberg JM. Osteoarticular infection complicating enterococcal endocarditis. Mayo Clin Proc. 2003;78(5):623-8. http:// dx.doi.org/10.4065/78.5.623 PMid:12744551.

Financial Support: This study was financed in part by the Coordenação de Aperfeiçoamento de Pessoal de Nível Superior - Brasil (CAPES) - Finance Code 001 and the Conselho Nacional de Desenvolvimento Científico e Tecnológico (CNPq) (\#310357/2018-7). 